\title{
FAKTOR-FAKTOR YANG MEMPENGARUHI MANAJEMEN PENDIDIKAN DAN PELATIHAN (DIKLAT) DALAM UPAYA PENGEMBANGAN SUMBER DAYA MANUSIA (SDM)
}

\author{
Edison Siregar \\ edison72gar@yahoo.com \\ Universitas Kristen Indonesia
}

\begin{abstract}
Every company is required to have qualified human resources and character. The availability of human resources that meet the needs of companies that have the ability, knowledge and skills as well as the character, it is necessary a method of human resource development. One way or method of human resource development is through education and training. The purpose of this paper is to know the factors that influence the management of education and training (Diklat) in the effort of human resource development. In describing the analysis of management and training, the authors use a system approach where described first about the concept of management education and training, then how the process of management education and training itself. The second approach is the input source approach to analyze the dominant factors in education and training management. There are at least seven dominant factors, namely: 1) Training Providers; 2) Instructor / Trainer; 3) Training Participants; 4) Education and Training Needs Planning; 5) Curriculum; 6) Facilities and Infrastructure; 7) Financing Education and training.
\end{abstract}

Keywords: Management, Education, Training, Human Resources

\begin{abstract}
ABSTRAK
Setiap perusahaan dituntut untuk memiliki sumber daya manusia yang berkualitas dan berkarakter. Ketersediaan sumber daya manusia yang memenuhi kebutuhan perusahaan yang mempunyai kemampuan, pengetahuan dan keterampilan serta yang berkarakter, maka diperlukan suatu metode pengembangan sumber daya manusia. Salah satu cara atau metode pengembangan sumber daya manusia adalah melalui pendidikan dan pelatihan. Tujuan penulisan ini untuk mengetahui faktorfaktor yang mempengaruhi manajemen pendidikan dan pelatihan (Diklat) dalam upaya pengembangan sumber daya manusia. Dalam mendiskripsikan analisis manajemen dan pelatihan, penulis menggunakan pendekatan sistem dimana dijabarkan terlebih dahulu mengenai konsep
\end{abstract}


manajemen pendidikan dan pelatihan, kemudian bagaimana proses manajemen pendidikan dan pelatihan itu sendiri. Pendekatan yang kedua adalah pendekatan sumber masukan untuk menganalisis faktor-faktor yang dominan dalam manajemen pendidikan dan pelatihan. Terdapat paling sedikit tujuh faktor yang dominan, yaitu: 1) Penyelenggara Diklat; 2) Instruktur/Pelatih; 3) Peserta; 4) Perencanaan Kebutuhan Pendidikan dan Pelatihan; 5) Kurikulum; 6) Sarana dan Prasarana; 7) Pembiayaan.

Kata kunci: Manajemen, Pendidikan, Pelatihan, Sumber daya manusia

\section{PENDAHULUAN}

Dalam keadaan situasi persaingan yang sangat ketat di era globalisasi, setiap perusahaan dituntut untuk dapat beradaptasi dan mampu mengelola sumberdaya yang dimiliki. Sumber daya manusia (SDM) yang berkualitas dan berkarakter menjadi penting peranannya agar perusahaan dapat bertahan bahkan unggul dalam persaingan tersebut.

Ketersediaan sumber daya manusia yang memenuhi kebutuhan perusahaan baik kualitas maupun kuantitas dalam arti mempunyai kemampuan, pengetahuan dan keterampilan serta yang berkarakter, maka diperlukan suatu metode pengembangan sumber daya manusia. Pengembangan sumber daya manusia merupakan kegiatan yang dilakukan oleh perusahaan untuk meningkatkan pengetahuan kemam-puan (knowledge), keterampilan (skill) pegawainya sesuai dengan tuntutan pekerjaan yang dilaku-kan. Dengan kegiatan pengembangan ini diharapkan pegawai dapat memperbaiki dan mengatasi kekurangan dalam melaksanakan pekerjaannya agar dapat lebih baik sesuai perkembangan ilmu dan teknologi. Salah satu cara atau metode yang sering digunakan dalam pengembangan sumber daya manusia adalah melalui pendidikan dan pelatihan. Pendidikan dan pelatihan merupa-kan metode untuk meningkatkan kemampuan seseorang dan untuk menjembatani adanya gap atau perbedaan antara kemampuan dan keterampilan yang sekarang dimiliki dengan kemampuan dan keterampilan standard yang ditetapkan.

Pengembangan sumber daya manusia menurut Malayu (2003, h. 68) adalah suatu usaha untuk meningkatkan kemampuan teknis, teoritis, konseptual, dan moral karyawan sesuai dengan kebutuhan pekerjaan/jabatan melalui pendidikan dan latihan. Sementara itu Ranupandojo dan Husnan dalam Suwatno dan Priansa (2012, h. 208) mengatakan bahwa Pendidikan dan pelatihan merupakan suatu hal yang tidak bisa dipisahkan 
Siregar, Faktor-Faktor yang Mempengaruhi Manajemen Pendidikan dan Pelatihan (DIKLAT) dalam Upaya Pengembangan Sumber Daya Manusia (SDM)

dalam dunia ketenagakerjaan. Pada dasarnya pendidikan dan pelatihan memberikan bantuan kepada karyawan agar dapat meningkat-kan kemampuan kerja dan menumbuhkan pengertian tentang status dirinya dan tujuan perusahaan. Dengan kata lain setiap kegiatan dibidang pendidik-an dan pelatihan pada dasarmya adalah usaha-usaha untuk meningkatkan pengetahuan, sikap dan keterampilan agar menghasil-kan kinerja yang efektif dan efisien.

Daryanto dan Bintoro (2014, h. 33) mengatakan bahwa kegiatan-kegiatan pendidikan dan pelatihan (diklat) dilaksanakan sebagai upaya yang disebabkan karena kekurangmampuan manusiawi (humanistic skill), kurangnya kemampuan teknis (technical skill), atau kurangnya kemampuan manajerial (manajerial skill). Dengan pemahaman akan pentingnya meningkatkan kualitas kemampuan yang menyangkut kemampuan kerja, berpikir dan keterampilan, maka pendidikan dan pelatihan mempunyai peran yang sangat diperlukan sebagaimana yang dikemukakan oleh Notoatmodjo (2010, h. 4), bahwa Pendidikan dan pelatihan adalah merupakan upaya untuk mengembangkan sumber daya aparatur, terutama untuk peningkatan profesionalime yang berkaitan dengan, keterampilan administrasi dan keterampilan manajemen (kepemimpinan).

Pendidikan dan Pelatihan merupakan dua hal makna dan fungsi yang hampir sama, hanya ruang lingkupnya saja yang membedakan gerak kedua kegiatan tersebut. Menurut Ranupandojo dan Husman (2011, h. 4) pendidikan merupakan usaha kegiatan untuk meningkatkan pengetahuan umum seseorang termasuk di dalamnya teori untuk memutuskan persoalan-persoalan yang menyangkut kegiatan pencapaian tujuan. Sedangkan latihan merupakan kegiatan untuk memperbaiki kemampuan kerja melalui pengetahuan praktis dan penerapannya dalam usaha pencapaian tujuan. Pengertian yang sama disampaikan Suwanto dan Priansa (2012, h. 208) bahwa pendidikan merupakan suatu kegiatan untuk meningkatkan pengetahuan umum seseorang termasuk didalamnya peningkatan penguasaan teori dan keterampilan memutuskan terhadap persoal-an-persoalan yang menyangkut kegiatan mencapai tujuan. Pelatihan adalah suatu kegiatan untuk memperbaiki kemampuan kerja seseorang, membantu memahami suatu pengetahuan praktis dan penerapannya guna meningkatkan keterampilan, kecakapan dan sikap yang diperlukan organisasi dalam usaha mencapai tujuannya.
Noe
(2010,
h. 5)

menghubungkan pendidikan dan pelatihan dengan upaya perusahaan dalam memfasilitasi karyawan untuk belajar tentang kompetensi yang terkait dengan pekerjaannya, seperti pengetahuan, keterampilan, dan 
tingkat laku sehingga dapat diterapkan dalam aktivitas seharihari, seperti yang dikemukakannya bahwa Training refers to a planned effort by a company to falilitate employees learning of job-related competen-cies. These competencies include knowledge, skills, or behaviors that are critical for successful job performance. The goal of training is for employees to master the knowledge, skill, and behaviors emphasized in training programs and to apply them to their day-today actities."

\section{PEMBAHASAN}

Manajemen Pendidikan dan Pelatihan Dalam Pendekatan Sistem.

\section{Konsep Manajemen Pendidik-an dan Pelatihan}

Istilah manajemen sering diartikan sebagai cara atau usaha yang dilakukan untuk mencapai tujuan yang telah ditetapkan dengan memanfaatkan sumber daya yang dimiliki. Manajemen diklat adalah upaya yang sistematis dan terencana dalam mengoptimalkan seluruh komponen diklat guna mencapai tujuan program secara efektif dan efesien. Agar tujuan dapat tercapai maka manajemen diklat dapat menggunakan fungsifungsinya, yaitu perencanaan (planning), pengorganisasian (organizang), pelaksanaan (actuating), penataan staf (staffing), pengarahan (directing), pengendalian (controlling), dan evaluasi (evaluating).
Sebagai suatu proses, istilah manajemen pendidikan dan pelatihan berkaitan dengan siklus yang menurut Notoatmodjo (2009, h. 18) secara garis besar adalah sebagai berikut:

a. Analisis Kebutuhan Pelatihan (Training Need Assesment), yang bertujuan untuk mencari atau mengidentifikasi kemampuan-kemampuan yang diperlukan oleh karyawan dalam rangka menunjang ke-butuhan organisasi.

b. Menetapkan Tujuan Pelatihan, berupa perumusan kemampu-an yang diharapkan dari pelatihan tersebut yaitu adanya perubahan kemam-puan.

c. Pengembangan Kurikulum, yaitu menentukan metoda belajar mengajar yang akan digunakan, serta alat bantu belajar mengajar yang diperlukan dalam pelatihan tersebut.

d. Persiapan Pelaksanaan Diklat. Sebelum pendidikan dan pelatihan dilaksanakan, terlebih dahulu dilakukan persiapan yang pada umumnya mencakup kegiatan-kegiatan administrasi.

e. Pelaksanaan Diklat,

d. Evaluasi, yang mencakup (1) Evaluasi terhadap proses kegiatan Diklat, dan (2) evaluasi terhadap hasil dari kegiatan diklat.

Dalam konteks pelaksanaan pendidikan dan pelatihan secara operasional, maka fungsi 
Siregar, Faktor-Faktor yang Mempengaruhi Manajemen Pendidikan dan Pelatihan (DIKLAT) dalam Upaya Pengembangan Sumber Daya Manusia (SDM)

manajemen itu sebagaimana yang dikemukakan Fakry Gaffar (1989, h. 40) akan meliputi dua aspek, (1) manajemen proses belajar mengajar (PBM) sebagai fungsi primer, dan (2) manajemen layanan administratif sebagai fungsi sekunder. Manajemen PBM dikatakan sebagai fungsi primer dari manajemen diklat, karena tujuan institusional dari keseluruhan manajemen diklat tidak lain adalah agar tercapai kondisi the better learning sebagai syarat bagi perolehan kinerja profesional pada lulusan.

\section{Proses \\ Manajemem \\ Pendidikan dan Pelatihan dalam konteks Sistem}

Sistem dapat diartikan sebagai suatu susunan terpadu dan terdiri atas bagian-bagian yang saling berhubungan, saling berinteraksi dan saling mendukung antar bagiannya serta membentuk satu kesatuan yang utuh. Konsep diklat sebagai suatu sistem merupakan seperangkat komponen atau unsur-unsur atau sub sistem yang saling berinteraksi untuk mengubah kompetensi kerja pegawai/karyawan/orang sehingga dapat berprestasi lebih baik dalam jabatannya melalui proses belajar dalam kegiatan diklat.

Proses manajemen pendidikan dan pelatihan (diklat) dalam konteks sistem dapat dikaitkan sebagai sistem hubungan sebab dan akibat yang terdiri dalam 3 komponen, yaitu input (masukan), proses dan output (keluaran). Komponen masukan terdiri dari penyelenggara, instruktur/pelatih, peserta diklat, perencanaan kebutuhan pelatihan, kurikulum, sarana dan prasarana, dan pembiayaan ; komponen proses terdiri atas proses belajar mengajar dan pengelolaan administratif; komponen keluaran terdiri atas kompetensi dan kinerja peserta.

Keterkaitan antar komponen dan unsur-unsur dalam sistem manajemen pendidikan dan pelatihan digambarkan sebagai berikut.

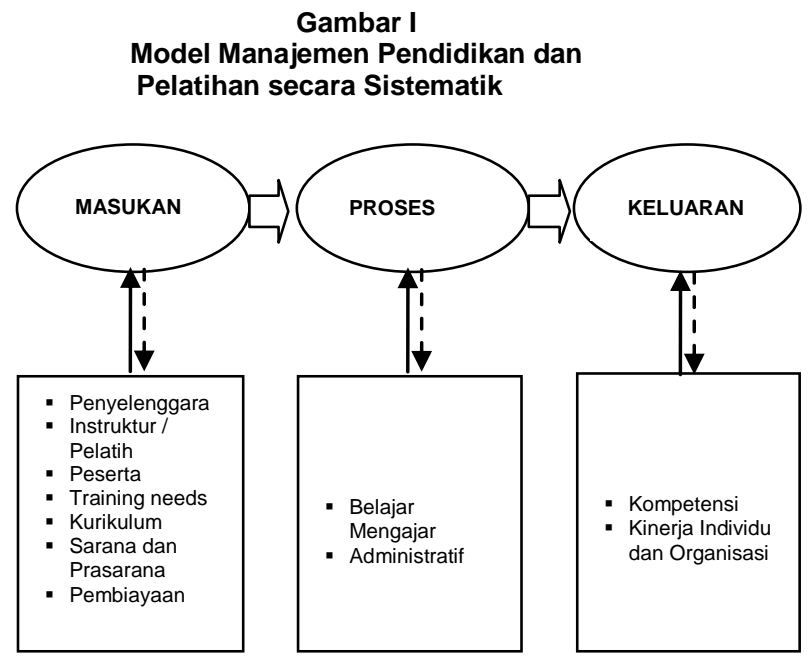

\section{Faktor-Faktor Mempengaruhi Diklat}

Apabila kita ingin menggunakan pendekatan sumber masukan untuk menganalisa faktor-faktor yang dominan berpengaruh dalam manajemen pendidikan dan pelatihan, dapat diidentifikasi paling sedikit tujuh faktor, yaitu:

\section{Penyelenggara}

Penyelenggara diklat merupa-kan komponen penting 
dalam mendukung keberhasilan suatu diklat. Profesionalisme lembaga diklat sangat ditentukan oleh profesionalisme penyelenggaranya karena penyelenggara mempunyai akses terhadap sumber-sumber yang diperlukan untuk mempe-lancar penyelenggaraan diklat. Penyelenggara diklat dapat terdiri atas pimpinan dan pelaksana. Pimpinan biasanya mempunyai tugas dan fungsi dalam merencanakan, menetapkan kebijakan umum dan strategis diklat, mengambil keputusan, memberi arah, mengawasi dan mengendalikan hasil mutu diklat. Pelaksana adalah staf pegawai yang bertugas melaksanakan pekerjaan teknis administrative diklat untuk mendukung pelaksanaan kegiatan belajar mengajar dan latihan.

Penyelenggara diklat seharus-nya berlatar belakang pendidikan, pengalaman belajar yang memadai di bidang diklat. Artinya, penye-lenggara ini memiliki wawasan dan kompetensi professional dan personal di bidang pengelolaan diklat.

\section{Instruktur/Pelatih}

Instruktur/Pelatih adalah seseorang yang diberi tugas, tanggung jawab, wewenang dan hak secara penuh untuk melaksanakan kegiatan pelatihan dan pembelajaran kepada peserta pelatihan dibidang tertentu.

Seorang Instruktur/Pelatih harus kompeten dalam bidangnya dan dituntut kreatif, agar tercipta suasana belajar yang nyaman, menyenangkan, dan efektif. Selain itu, seorang Instruktur/Pelatih dituntut menguasai misi yang diembannya, berpengetahuan dan berpengalaman dalam bidang yang menjadi keahliannya untuk dapat ditransfer kepada peserta diklat. Notoatmodjo (2003, h. 107) mengata-kan "Instruktur adalah guru, ia harus profesional dalam keguruannya". Pendapat tersebut pada dasarnya menekankan, bahwa seorang instruktur harus selalu mengembangkan diri sesuai dengan perkembangan ilmu pengetahuan dan teknologi, khususnya dalam bidang pekerjaan yang ia geluti. Seorang guru atau instruktur dituntut untuk selalu kreatif mengembang-kan kemampuannya agar mampu menciptakan pengalaman belajar yang sesuai dengan tuntutan masyarakat.

Kualitas seorang istruktur/ pelatih sangat mempengaruhi kualitas sasaran peserta didik. Oleh karena itu, seorang istruktur/pelatih harus memiliki kemampuan berikut: (1) penguasa-an materi yang akan diajarkan; (2) kemampuan menyusun materi ajar; (3) kemampuan memilih dan mengembangkan metode pembelajaran; (4) kemampuan menggunakan media dan sumber-sumber belajar; (5) kemampuan mengelola kelas; dan (6) kemampuan ber-komunikasi dan membina hubungan dengan peserta diklat. 
Siregar, Faktor-Faktor yang Mempengaruhi Manajemen Pendidikan dan Pelatihan (DIKLAT) dalam Upaya Pengembangan Sumber Daya Manusia (SDM)

\section{Peserta}

Dalam

suatu

penyelenggaraan diklat, sering terjadi bahwa peserta yang hadir membawa motif yang beragam. Ada yang hadir sebagai peserta karena memang sekedar mencari kesempatan untuk keluar dari rutinitas kerja di lembaganya masing-masing, ada yang sekedar diperintah oleh pimpinannya, ada yang memang merasa membutuhkan materi yang akan diperoleh melalui kegiatan diklat sehingga dapat dikatakan bahwa peserta diklat merupakan segmen penting dalam suatu organisasi, karena dianggap berperan memberikan sumbangan bagi tercapainya tujuan organisasi. Oleh karena itu kedudukan peserta diklat dalam program pendidikan dan pelatihan sangat penting artinya untuk menentukan program diklat yang akan dilaksanakan

Peserta diklat mempunyai latar belakang yang tidak sama atau heterogen seperti pendidikan dasarnya, pengalaman kerjanya, usianya dan lain sebagainya. Hal ini akan menyulitkan dan menghambat pelaksanaan diklat karena daya tangkap, persepsi dan daya nalar mereka terhadap materi yang diberikan berbeda. Karena itu karakteristik seorang peserta sangat diperlukan dalam suatu penyelenggaraan diklat agar dapat tercapai tujuan yang diharapkan baik organisasional maupun pribadi peserta. Nasution (1998, hh. 38-46) dan Broad \& Newstrom (1992: 10) menjelaskan bahwa dalam diri peserta diklat terdapat karakteristik yang dapat memengaruhi prestasi belajar, yaitu (1) bakat untuk mempelajari sesuatu, (2) kesanggupan untuk memahami pelajaran, ketekunan dan motivasi, (4) waktu yang tersedia untuk belajar. (5) kemampuan dan bakat, (6) kebutuhan berprestasi (need of achievement), dan (7) motivasi.

\section{Perencanaan Kebutuhan Pendidikan dan Pelatihan}

Kebutuhan akan pendidikan dan pelatihan, menurut Veithzal dalam Basri (2015, h. 52) dapat digolongkan dalam tiga kebutuhan, yaitu (1) kebutuhan memenuhi kebutuhan sekarang. Kebutuhan ini dikenali dengan prestasi karyawan yang tidak sesuai dengan standar hasil kerja yang dituntut dalam suatu jabatan atau pekerjaan, (2) Memenuhi kebutuhan tuntutan jabatan lainnya, (3) untuk memenuhi tuntutan perubahan baik internal maupun eksternal.

Perencanaan pendidikan dan pelatihan menurut Scarvello \& Ledvinka (1998,h. 12) harus didasarkan kepada analisis kebutuhan yang mencakup tiga dimensi, yaitu (1) analisis kebutuhan sumber daya manusia secara kuantitatif dan kulitatif, yang didasarkan kepada jumlah kebutuhan sumber daya manusia untuk waktu dan bidang kerja atau jabatan tertentu, (2) analisis jabatan, yang akan menentukan jabatan serta kinerja jabatan tertentu yang akan dianalisis, dan (3) perencanaan 
dan pengembangan karir pegawai.

Menurut Surya Soemantri dalam Basri (2015, h. 56), pendekatan dalam penentuan kebutuhan pelatihan atau diklat dilakukan dalam tiga tingkatan, yaitu tingkatan organisasi, jabatan/tugas, dan individu dan dilaksanakan dalam tiga kegiatan analisis, seperti berikut.

a. Analisis

merupakan

Organisasi, pemeriksaan terhadap jenis-jenis permasalahan yang dialami oleh organisasi dadn menyediakan informasi dalam penyusunan profil sebuh organisasi sehingga diketahui keadaan sebenarnya dari suatu organisasi.

b. Analisis Jabatan/Tugas, merupakan informasi tertulis mengenai pekerjaan apa saja yang harus dikerjakan dalam suatu perusahaan untuk mencapai tujuan. Pada dasarnya, analisis jabatan merupakan proses untuk menentukan prilaku yang tepat, dan kuantitas serta kualitas perilaku tersebut untuk melaksanakan sebuah pekerjaan. Analisis tugas ini dimaksud untuk menjawab pertanyaan tentang apa yang harus diajarkan pada seorang pegawai untuk menghasilkan kinerja yang efektif.

c. Analisis

Individu, dilaksanakan untuk menjawab pertanyaan tentang siapa yang memerlukan pelatihan dan jenis pelatihan apa yang diperlukan. Tujuan dari analisis individu adalah untuk memeriksa seberapa baik individu pegawai dalam melaksanakan pekerjaanpekerjaannya. Analisis individu memerlukan pemeriksaan yang cermat atas keahlian dan kemampuan setiap individu untuk menentkan beberapa kekurangan yang dapat dikoreksi melalui pelatihan. Dengan melakukan analisis individu akan didapatkan kebutuhan pelatihan yang diperlukan pegawai sehingga dapat diupayakan program pelatihan yang dapat menanggulangi masalah tersebut.

\section{Kurikulum Pendidikan dan Pelatihan}

Kurikulum merupakan pedoman dan pengelolaan bagi sistem pembelajaran, pemilihan sumber belajar, sistem evaluasi, dan juga segala aktivitas yang bertujuan untuk memberikan input pengetahuan bagi peserta didik, yang dikembangkan oleh suatu pihak atau lembaga dalm rangka menyelenggarakan kegiatan pendidikan dan pembelajaran untuk mencapai tujuan pendidikan. Notoatmodjo (2009, h. 22) mengatakan kurikulum merupakan bagian yang penting dalam proses pendidikan dan pelatihan. Proses pendidikan dan pelatihan tidak akan berjalan dan tujuan pendidikan tidak akan tercapai tanpa adanya kurikulum. Jadi kurikulum merupakan salah satu 
Siregar, Faktor-Faktor yang Mempengaruhi Manajemen Pendidikan dan Pelatihan (DIKLAT) dalam Upaya Pengembangan Sumber Daya Manusia (SDM)

alat yang penting guna mencapai tujuan pendidikan dan pelatihan yang dapat mencerminkan hasil pendidikan dan pelatihan.

UU No. 20 Tahun 2003 mengatakan bahwa kurikulum merupakan seperangkat rencana \& sebuah pengaturan berkaitan dengan tujuan, isi, bahan ajar \& cara yang digunakan sebagai pedoman dalam penyelenggaraan kegiatan pembelajaran untuk mencapai sebuah tujuan pendidikan nasional. Sementara Dakir (2004) mengartikan kurikulum sebagai suatu program pendidikan yang berisikan berbagai bahan ajar dan pengalaman belajar yang di programkan, di rencanakan dan di rancangkan secara sistemik atas dasar norma-norma yang berlaku yang dijadikan pedoman dalam proses pembelajaran bagi tenaga kependidikan dan peserta didik untuk mencapai tujuan pendidikan.

Kurikulum menurut Rudi susilana (2010) merupakan suatu sistem yang memiliki komponenkomponen tertentu. Dan sistem kurikulum terbentuk oleh empat komponen, yaitu komponen tujuan, isi kurikulum, metode atau strategi pelaksanaan dan komponen evaluasi. Sebagai suatu sistem setiap komponen harus saling berkaitan antara satu sama lain.

Dengan demikian kurikulum bukanlah semata-mata susunan mata ajaran dalam suatu program pendidikan saja, melainkan meliputi rumusan tujuan, bahan apa yang sesuai dengan tujuan, bagaimana bahan itu bisa ditransformasikan, dan apakah bahan yang ditransformasikan itu mencapai sasaran atau tidak.

\section{a. Komponen Tujuan}

Mengingat kurikulum adalah alat untuk mencapai tujuan pendidikan, maka tujuan kurikulum menurut Nana Sudjana (2008) harus dijabarkan dari tujuan umum pendidikan. Berdasarkan hakekat dari tujuan dijabarkan sejumlah tujuan kurikulum mulai dari tujuan kelembagaan pendidikan, tujuan setiap mata pelajaran atau bidang studi sampai kepada tujuan-tujuan pengajaran.

Menurut Wina Sanjaya, (2009, h. 101), ada beberapa alasan mengapa tujuan perlu dirumuskan dalam kurikulum. Pertama, tujuan erat kaitannya dengan arah dan sasaran yang harus dicapai oleh setiap upaya pendidikan. kurikulum merupakan alat untuk mencapai tujuan pendidikan, dengan demikian perumusan tujuan merupakan salah satu komponen yang harus ada dalam sebuah kurikulum. Kedua, melalui tujuan yang jelas, maka dapat membantu para pengembang kurikulum dalam mendesain model kurikulum yang dapat digunakan bahkan akan membantu guru dalam mendesain sistem pembelajaran. Ketiga, tujuan kurikulum yang jelas dapat digunakan sebagai kontrol dalam menentukan batasbatas dan kualitas pembelajaran.

Rumusan tujuan dalam kurikulum pendidikan dan pelatihan terdiri atas beberapa 


\begin{abstract}
bentuk, yaitu (1) tujuan institusional, yaitu rumusan tujuan kelembagaan yang ingin dicapai; (2) tujuan kurikuler, yaitu tujuan kurikulum yang ingin dicapai untuk setiap jenis program, dan (3) tujuan instruksional, yaitu tujuan yang ingin dicapai pada setiap jam pertemuan belajar. Masingmasing rumusan tujuan ini merupakan penjabaran dari tujuan sebelumnya. Jadi untuk mencapai tujuan kelembagaan, maka dijabarkan kepada tujuan kurikuler, selanjutnya dari tujuan kurikuler dijabarkan tujuan institusional umum dan kemudian dijabarkan lagi tujuan instruksional khusus, yaitu perubahan perilaku yang diharapkan setelah satuan bahasan pelajaran disajikan.
\end{abstract}

\section{b. Isi Kurikulum}

Isi kurikulum/bahan ajar merupakan materi yang di ajarkan kepada siswa atau peserta didik, baik berupa pengetahuan, nilai-nilai, maupun kemampuan tertentu, dimana siswa diharapkan dapat menguasainya melalui pelaksanaan kurikulum yang diberlakukan dalam institusi pendidikan. materi kurikulum berkenaan dengan bahan pelajaran yang harus dikuasai siswa sesuai dengan tujuan pembelajaran. Materi pelajaran harus digali dari berbagai sumber belajar sesuai dengan kompetensi yang harus dicapai.

\section{c. Metode atau Strategi Pelaksanaan \\ Metode adalah seperangkat cara, jalan, dan teknik yang}

digunakan oleh pendidik dalam proses pembelajaran agar peserta didik dapat mencapai tujuan pembelajaran. Keberhasilan proses belajar mengajar merupakan indikator keberhasilan pelaksaan kurikulum selama proses belajar mengajar berlangsung.

Yang dimaksud dengan
strategi pelaksanaan disini
adalah upaya yang dilakukan untuk mentransformasikan bahan pelajaran yang telah dirumuskan dalam kurikulum. Strategi itu paling sedikit meliputi empat kegiatan, yaitu penyiapan bahan pelajaran, penyajian bahan, penggunaan media belajar, pengelolaan proses belajar dan latihan, serta penggunaan evaluasi.

Yang dimaksud dengan strategi pelaksanaan disini adalah upaya yang dilakukan untuk mentrans-formasikan bahan pelajaran yang telah dirumuskan dalam kurikulum. Strategi itu paling sedikit meliputi empat kegiatan, yaitu penyiapan bahan pelajaran, penyajian bahan, penggunaan media belajar, pengelolaan proses belajar dan latihan, serta penggunaan evaluasi.

Ada beberapa metode diklat yang dapat dikembangkan. Menurut Cherrington dalam Hasan Basri (2015), dikatakan bahwa metode dalam pendidikan pelatihan secara garis besar dibagi menjadi 2 yaitu on the job training dan off the job training. On the job training lebih banyak digunakan dibandingkan dengan off the job training. Hal ini 
Siregar, Faktor-Faktor yang Mempengaruhi Manajemen Pendidikan dan Pelatihan (DIKLAT) dalam Upaya Pengembangan Sumber Daya Manusia (SDM)

disebabkan karena metode on the job training lebih berfokus pada peningkatan produktivitas secara cepat, sedangkan metode off the job training lebih cenderung berfokus pada perkembangan dan pendidikan jangka panjang. Metode On the job training, antara lain: Job instruclion training,

Apprenticeship, Job rotation dan transfer, Couching dan counseling; sementara Off the Job Training terdiri dari: Vestibule training, Lecture, Independent self-study, Visual presentations, Conferences dan discussion, Case studies, Role playing, Simulation, Programmed instruction, Computer-based training, Laboratory training.

\section{d. Komponen Evaluasi}

Evaluasi merupakan bagian yang tak terpisahkan dari strategi pelaksanaan, baik evaluasi yang bersifat formatif maupun sumatif. Evaluasi formatif dapat dilakukan setiap pertemuan belajar, atau pada waktu tertentu yang dianggap penting dengan tujuan untuk memberikan umpan balik kepada peserta diklat dalam rangka penguasaan kemampuan dan ketrampilan. Evaluasi sumatif dilakukan pada setiap akhir program pendidikan untuk mengetahui sejauhmana kemampuan, kemajuan dan prestasi yang diraih peserta selama mengikuti diklat dalam jangka waktu tertentu, atau pada akhir diklat yang diikuti.

\section{Sarana dan Prasarana}

Konsekuensi dari kurikulum dan program diklat yang telah direncanakan adalah tersedianya sarana dan prasarana. Secara teoritis, dalam perencanaan pendidikan, khususnya yang berhubungan dengan spesifikasi pendidikan, maka sarana dan prasarana pendidikan akan diketahui wujudnya kalau program pendidikannya telah ditentukan.

Pelaksanaan diklat tidak akan berjalan maksimal apabila tidak memiliki fasilitas yang memadai. Pengelolaan sarana dan prasarana merupakan kegiatan yang amat penting, karena keberadaannya akan sangat mendukung suksenya proses diklat. Hal ini sejalan dengan pandangan Mulyasa (2007, h. 49), bahwa sarana pendidikan adalah peralatan dan perlengkapan yang secara langsung dipergunakan dan menunjang proses pendidikan, khususnya dalam proses belajar mengajar, sementara yang dimaksudkan dengan prasarana adalah fasilitas yang secara tidak langsung menunjang jalannya proses diklat.

Pada umumnya sarana dan prasarana yang dibutuhkan untuk suatu program diklat yang ideal meliputi: ruang kelas, ruang kantor dan pelayanan administrasi, ruang perpustakaan, ruang Instruktur/Pelatih, ruang aula, ruang laboratorium, ruang workshop dan praktikum, Disamping ruangan, maka dibutuhkan perangkat perlengkapan diklat yang 
mendukung teknis pelaksanaan kurikulum seperti peralatan dan media pembelajaran. . Nasution (1998, hh. 38-46)

\section{Pembiayaan Pendidikan dan Pelatihan}

Pembiayaan (dana) pendidikan dan pelatihan (diklat) merupakan salah satu komponen masukan (input) yang sangat penting dalam penyelenggaraan pendidikan dan pelatihan. Dalam setiap upaya pencapaian tujuan pendidikan dan pelatihan, baik tujuan-tujuan yang bersifat kuantitatif, pembiayaan pendidikan memiliki peran yang sangat menentukan. Hampir tidak ada upaya pendidikan yang dapat mengabaikan peranan pembiayaan, sehingga dapat dikatakan bahwa tanpa biaya, proses pendidikan tidak akan berjalan.

Keberhasilan suatu program pendidikan dan pelatihan lebih banyak ditentukan oleh seberapa besar pembiayaan (dana) yang dianggarkan dalam perencanaan penyelenggaraan suatu diklat.

Dalam Peraturan Pemerintah Nomor 19 Tahun 2005 tentang Standar Nasional Pendidikan (SNP) Pasal 62 disebutkan bahwa pembiayaan pendidikan terdiri atas biaya investasi, biaya operasi, dan biaya personal (Depdiknas, 2005). Biaya investasi satuan pendidikan meliputi biaya penyediaan sarana dan prasarana, pengembangan sumber daya manusia, dan modal kerja tetap. Biaya operasi satuan pendidikan meliputi: gaji pendidik dan tenaga kependidikan serta segala tunjangan yang melekat pada gaji; bahan atau peralatan habis pakai; dan biaya operasi pendidikan tak langsung berupa daya, air, jasa telekomunikasi, uang lembur, transportasi, konsumsi, pajak, asuransi, dan lain sebagainya. Adapun biaya personal meliputi biaya pendidikan yang harus dikeluarkan oleh peserta didik untuk bisa mengukuti proses pembelajaran secara teratur dan berkelanjutan (Depdiknas, 2005).

Secara umum, pembiayaan pendidikan dibedakan menjadi dua jenis, yaitu:

1. Biaya rutin (recurring cost), pada intinya mencakup keseluruhan biaya operasional penyelenggaraaan pendidikan, seperti biaya administrasi, pemeliharaan fasilitas, pengawasan, gaji, biaya untuk kesejahteraan, dan lain-lain. Biaya rutin adalah biaya yang harus dikeluarkan dari tahun ke tahun, seperti gaji pegawai (guru dan non guru), serta biaya operasional, biaya pemeliharaan gedung, fasilitas dan alat-alat pengajaran (barang-barang habis pakai).

2. Biaya modal (capital cost) atau sering pula disebut biaya pembangunan mencakup biaya untuk pembangunan fisik, pembelian tanah, dan pengadaan barang-barang lainnya yang didanai melalui anggaran pembangunan. 
Siregar, Faktor-Faktor yang Mempengaruhi Manajemen Pendidikan dan Pelatihan (DIKLAT) dalam Upaya Pengembangan Sumber Daya Manusia (SDM)

Biaya pem-bangunan,
misalnya, biaya pembelian
atau pengembangan tanah,
pembangunan gedung,
perbaikan atau rehab
gedung, penambahan
furnitur, serta biaya atau
pengeluaran lain unutk
barang-barang yang tidak
habis pakai
Pengelolaan pembiayaan
na) pendidikan dan pelatihan
tilaksanakan dengan baik
teliti mulai dari tahap
nyusunan anggaran,
nggunaan, sampai
abawasan dan pertanggung-
aban sesuai dengan
entuan yang berlaku.

\section{SIMPULAN}

Berdasarkan pembahasan diatas dapat disimpulkan bahwa salah satu sumber daya yang dimiliki oleh organisasi adalah sumber daya manusia. Sumber daya manusia (SDM) yang berkualitas dan berkarakter menjadi penting peranannya agar organisasi dapat bertahan bahkan unggul dalam persaingan yang semakin ketat.

Ketersediaan sumber daya manusia yang memenuhi kebutuhan perusahaan baik kualitas maupun kuantitas dalam arti mempunyai kemampuan, pengetahuan dan keterampilan serta yang berkarakter, maka diperlukan suatu metode pengembangan sumber daya manusia, dan salah satu cara atau metode yang sering digunakan dalam pengembangan sumber daya manusia adalah melalui pendidikan dan pelatihan.

Proses manajemen pendidikan dan pelatihan (diklat) dalam konteks sistem dapat dikaitkan sebagai sistem hubungan sebab dan akibat yang terdiri dalam 3 komponen, yaitu input (masukan), proses dan output (keluaran). Komponen input (masukan) yang terdiri dari penyelenggara, instruktur/pelatih, peserta diklat, perencanaan kebutuhan pelatihan, kurikulum, sarana dan prasarana, dan pembiayaan merupakan faktorfaktor yang secara dominan mempengaruhi manajemen pendidikan dan pelatihan (diklat).

\section{ACUAN PUSTAKA}

Basri, Hasan \& Rusdiana. (2015). Manajemen Pendidikan dan Pelatihan. Bandung: CV. Pustaka Setia.

Broad, M. L., and Newston, J.W. (1992). Transfer of Training, Action - Packed Strategies To Ensure High Pay of From training Investments.

Massachusetts: Addition Wesley Pub.

Dakir. (2004). Perencanaan Dan

Pe-ngembangan

Kurikulum. Jakarta: Rineka Cipta.

Daryanto dan Bintoro. (2014). Manajemen Diklat. Yogyakarta: Gava Media.

Fakry, G. (1989). Perencanan dan

Manajemen 
Pendidikan. Bandung: FPs. IKIP Bandung.

Malayu, S. P. H. (2003). Manajemen Sumber Daya Manusia. (Edisi Revisi Cetakan ke-8). Jakarta: PT. Bumi Aksara.

Mulyasa, E. (2007). Manajemen Berbasis Sekolah. Bandung: Remaja Rodakarya.

Nasution, S. (1998). Metode Penelitian naturalistik Kualitatif. Bandung: Tarsito Noe, Raymond A. (2010). Employee Training and Development. Fifth Edition. New York: McGraw-Hill.

Notoatmodjo, S. (2010). Bisnis, Manajemen \& Keuangan. Jakarta: Rineka Cipta.

Notoatmodjo, S. (2009). Pengembangan Sumber Daya Manusia. Jakarta: Rineka Cipta.

Peraturan Pemerintah Republik Indonesia No. 19 Tahun 2005 tentang Standar Nasional Pendidikan. Jakarta

Ranupandojo, H. dan Husnan, S. (2011). Manajemen Personalia. Edisi Keempat. Yogyakarta: BPFE.

Sanjaya,W. (2009). Kurikulum dan Pembelajaran, Teori dan Praktek Pengembangan Kurikulum Tingkat satuan Pendidikan (KTSP). Jakarta: Kencana Prenada.
Scarpello, V. G., and Ledvinka, J. (1988). Personnel / Human resource management, Environments and Functions. Boston:Pws-Kent Pu-blishing Company.

Silberman, M. (2006). Active Training, 3rd Edition. San Francisco: John Wiley \& Sons, Inc.

Sudjana, N. (2008). Pembinaan Dan Pengembangan Kurikulum Di Sekolah. Bandung: Sinar Baru Algensindo.

Susilana, R. (2016). Komponenkomponen Kurikulum. Bandung: Universitas Pendidikan Indonesia.

Suwatno dan priansa (2012). Dasar-dasar Manajemen Dalam Organisasi Publik dan Bisnis. Bandung:UPI Press.

Undang-Undang Republik Indonesia Nomor 20 Tahun 2003 tentang Sistem Pendidikan Nasional. 